\title{
THE PARAMETERS OF THE QUALITY OF TEACHING OF THE TECHNIQUE
}

\author{
Čestmír SERAFÍN*, Univerzita Palackého v Olomouci
}

Přijato: 16. 2. 2015 / Akceptováno: 25. 5. 2015

Typ článku: Výzkum

DOI: $10.5507 /$ jtie.2015.007

Abstract: In Czech society, the concept of the quality of teaching is very often cited for several decades. This concept is presented in a statement of politicians in the country strategy papers, as well as in discussions of the professional public. The aim of the study is given here to look at this concept from the angle devoted to technology and the teaching of the technique, which in recent years have vanished from schools, or educational content is narrowed to only one phenomenon, and the information and communication technologies

Key words: educational quality; quality of school; school, instruction; research, education; instruction on technique, subject didactics.

\section{PARAMETRY KVALITY VÝUKY O TECHNICE}

Resumé: $V$ české společnosti je pojem „,kvalita výuky“ velmi často uváděn již po několik desitek let. Tento pojem je uváděn $v$ prohlášení politikü, ve strategických dokumentech $i v$ diskuzich odborné veřejnosti. Cílem zde uvádèné studie je podat pohled na tento pojem z úhlu věnujicího se technice a výuce o technice, která se právě v poslednich létech vytratila ze vzdělávacího obsahu škol, resp. se zúžila pouze na jeden fenomén a tím jsou informační a komunikační technologie.

Klíčová slova: kvalita výuky; kvalita vzdělávání; škola; výuka; výzkum; vzdělávání; výuka o technice; oborová didaktika. 


\section{Př́stupy ke kvalitě výuky}

Pojem kvalita se v povědomí učitelské obce vyskytuje poměrně běžně. Problematika kvality vzdělávání či procesu výuky je obecně považována za relevantní a to jak pro učitele, tak ale také vzhledem ke snahám vzdělávací politiky „vyžadovat kvalitu výuky a tu zvyšovat" - což ovšem předpokládá ji také sledovat a určitým způsobem hodnotit.

Pojem kvalita je odvozen z latinského slova qualitas, které označuje vlastnost určitého předmětu či osoby, přičemž hodnocení kvality je vždy aspoň do určité míry subjektivní záležitost. Podle Pedagogického slovníku [1] se kvalita vzdělávání uplatňuje ve významu evaluačním, tj. jako úroveň produkce vytvářené jednotlivou školou, souborem škol určitého stupně či druhu nebo celou vzdělávací soustavou. Tato úroveň je jednak předepisována určitými kritérii, např. vzdělávacími standardy, jednak je měřena jako vzdělávací výsledky.

Jedním z možných príistupů $\mathrm{k}$ hodnocení kvality ve vzdělávání je systém řízení kvality podle norem ISO řady 9000 . Normy ISO 9000 popisují systém řízení v obecné rovině. A jsou určeny pro jakýkoliv typ organizace. Pro oblast vzdělávání byla zformulována Metodika ISO/IWA 2:2003 - směrnice pro aplikaci ISO 9001:2000 ve vzdělávání. ${ }^{2}$ ISO 9001:2000 je norma, tzn. statický model, na jehož základě se zjištuje míra shody procesů a postupů vzdělávací organizace se stanovenými požadavky.

Další možným př́stupem může být model excelence EFQM a od něho odvozený model pro veřejnou správu - model CAF. Tento systém je pokládán za dynamický, integrující v sebe různé prvky rrízení, jako je přístup TQM (komplexní rízení kvality), cyklus PDCA a benchmarking. Model excelence EFQM (viz obr. 1) je manažerský model, který vytvořila Evropská nadace pro management kvality $(\mathrm{EFQM})^{3}$, nezisková organizace založená v roce 1988 sdružující 700 firem a organizací z mnoha odvětví.

Model EFQM umožňuje:

- sebehodnocení dané organizace v oblastech její činnosti, přičemž toto hodnocení je členěno do devíti kritérí,

- benchmarking je soustavný, systematický proces zaměrující se na porovnání vlastní efektivnosti z hlediska produktivity, kvality a praxe se špičkovými společnostmi a organizacemi $v$ dané oblasti působení.

\footnotetext{
${ }^{2}$ Metodika ISO/IWA 2:2003 je smérnici pro aplikaci ISO 9001:2000 ve vzdělávání. Byla zpracována a vydána v roce 2003 na základě zkušeností s uplatňováním normy ISO 9001:2000. Tato metodika je založena na managementu procesu, tzn. na uplatňování procesního př́stupu. Pro zjištěni přidané hodnoty je nutné, aby jednotlivé procesy byly objektivně měřitelné (např. hodnoceni žáků, hodnoceni pracovniků, apod.). Metodika ISO/IWA 2:2003 se vztahuje k dalš́ normè ISO 9004:2000, Systémy managementu jakosti - Smérnice pro zlepšováni jakosti. Př́lohou této normy je Směrnice pro sebehodnocení.

${ }^{3}$ Evropská nadace pro management kvality (http://www.efqm.org/)
} 


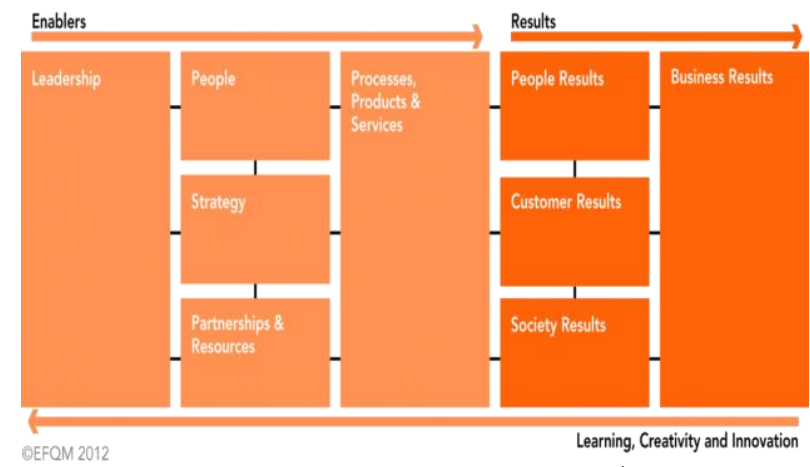

Obr. 1 EFQM Excellence Model ${ }^{4}$

Model EFQM je dynamickým analytickým nástrojem, kterým se lze vhodně zaměřit na růst školy. Tento model vytváŕí prostor ke zlepšování funkcí školy a integruje různé prvky řízení. Př́nosem aplikace modelu EFQM v podmínkách školství je provedení systematické, komplexní analýzy, představující sebehodnocení podle prověreného modelu. Na základě takovéto analýzy si pak škola může stanovit potřebné „ozdravné“ nástroje. Důležitým př́nosem aplikace toho modelu je otevření dialogu uvnitř školy, zaměřeného zejména na otázky strategického řízení, na probíhající procesy, silné a slabé stránky školy, tedy oblasti, které se často při běžném chodu školy pomíjejí z důvodu nedostatku času.

Sebehodnocením podle modelu EFQM si škola vlastně otevírá mnoho možností $\mathrm{k}$ diskusi o kvalitě procesů, rozdílnosti přístupů, $\mathrm{k}$ výměně dobré praxe a zkušeností i se školami, které aplikují stejný model.

$\mathrm{V}$ odborné literatuře (např. [2], [3], [4], [5], [6]), lze dovodit, že kvalita ve vzdělávacím procesu bývá vymezena přibližně ve třech základních rovinách (viz obr. 2):

1. kvalita vzdělávacího systému - myšleno vzdělávací politiky na úrovni státu;

2. kvalita školy - instituce, na jejíž existenci a fingování má vliv zrrizovatel, vedení školy, učitelé, žáci i jejich rodiče;

3. kvalita výuky ve vyučovacích jednotkách - zpravidla ve vyučovacích hodinách, kde probíhají především procesy vyučování a za jejiž kvalitu odpovídají hlavně sami učitelé ale také žáci.

Výše uvedené roviny a procesy, které v nich probíhají, nejsou samozřejmě disjunktní a nezávislé, právě naopak. Kvalita výuky je tak pochopitelnou součástí širšího rámce kvality školy, ta pak je součástí kvality celého vzdělávacího systému.

Podle Pedagogického slovníku [1] a další odborné pedagogické literatury je výuka širším pojmem vyučování, přičemž se jedná o organizovaný proces učení zahrnující činnost učitele i žáka, proces vyučování, cíle a obsah výuky. V rámci kvality výuky pak můžeme vymezit kvalitu vyučování. Do vlastního procesu výuky vstupuje velké množství faktorů, které vzájemně interagují. Podle dokumentu předloženému UNICEF na zasedání Mezinárodní pracovní skupiny pro vzdělávání [7] to jsou zejména:

${ }^{4}$ EFQM Excellence Model (http://www.efqm.org/efqm-model/efqm-model-in-action-0) 
- Žáci a studenti, jejich zázemí;

- škola, její struktura;

- učitelský sbor; jeho schopnosti a dovednosti, vzdělání;

- kutikulární dokumenty, vzdělávací politika;

- sociální důsledky.

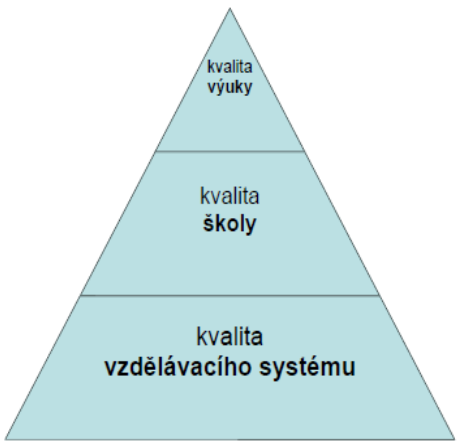

Obr. 2 Základni hladiny kvality vzděláváni

Výuka je tak mnohorozměrná ve svém popisu i obsahu a tato mnohorozměrnost se odráží i v tom, co vytvář́ její kvalitu. Lze tedy konstatovat, že neexistuje jednoduchý přepis jejich dosažení.

Složitost vymezení celého pojmu kvality výuky dokládá mj. např. H. Ditton [8]:

1. Při zkoumání kvality výuky jsou výchozí:

- normativní představy - např. o celkové podobě výuky, o vztahu mezi žáky a učitelem, o vztahu mezi žáky navzájem, o dodržování základních pravidel atd.;

- účinky výuky - např. výkony žáků, jejich postoje atd.

2. Zkoumání naplnění normativních představ a účinků výuky by se mělo orientovat na:

- cíle výuky;

- obsah výuky;

- metody výuky;

- strukturování výuky;

- klima při vyučování (i ve škole).

3. Zkoumání lze provádět interně i externě.

4. Zkoumání se může orientovat přímo na kvalitu dějů, které probíhají při vyučování, nebo na délku doby, po kterou tyto děje probíhají - obě hlediska však spolu obecně souvisí.

Při zjišstování kvality výuky se výzkumné přístupy zaměřují na [1]:

- charakteristiky procesuální (parametry);

- charakteristiky rezultativní (produktové) tj. vzdělávací výsledky dosahované prostřednictvím vyučování;

- charakteristiky klimatu tř́dy a klimatu školy. 
V procesuálně produktovém paradigmatu je možno kvalitu výuky chápat jako cestu a zároveň i cíl. V současné době se $\mathrm{v}$ odborných kruzích hovoř́i o nezbytnosti inovovat základní kutikulární dokumenty školy, včetně nikdy nekončícího procesu inovování činnosti učitele a to právě $v$ kontextu výše uvedeném ${ }^{5}$.

\section{Expertní šetření}

Ve výzkumu jsme se zaměřili na procesuální část procesuálně produktového paradigmatu. Impulzem pro toto šetření byly rozhory a experty a odborníky z praxe působící v oblasti technického vzdělávání, vycházející z predikce, že kvalita výuky je dána především učitelem vyplývající z jeho pedagogického jednání, z jeho osobnosti.

Hlavním cílem našeho výzkumu bylo určit techniku posuzování kvality výuky o technice a její ověření odbornou praxi, tj. ve vyučovacích hodinách předmětu člověk a svět práce na základních školách. Zejména se jednalo o:

- prověření možností, jak porovnat výuku různých učitelů;

- určení charakteristik výuky ze strany učitele;

- určení statistických dat ke kvalitativním ukazatelům;

- upřesnění nástroje.

Expertní šetření bylo realizováno v České republice oslovením vyučujících různých typů škol a školských zařízení zabývajících se technickým vzděláváním a to na základě využití dvou metod:

a) strukturované rozhovory;

b) dotazníky s otevřenými otázkami.

Volba strukturovaného rozhovoru vhodně doplňuje dotazníkové šetření k chápání kvality výuky:

1. při strukturovaném rozhovoru lze pružně reagovat na odpovědi respondenta;

2. odpovědi respondenta bývají obsáhlejší, než v písemné podobě;

3. pro respondenta je ústní forma mnohdy výhodnější a jednodušší.

V tabulce 1 jsou heslovitě uvedeny parametry kvalitní výuky o technice, které vyplynuly ze strukturovaných rozhovorů a posléze z dotazníků. Pořadí uváděných parametrů je však pouze orientační a nelze ho $\mathrm{v}$ žádném př́ípadě absolutizovat.

$\mathrm{Na}$ základě expertního šetření $\mathrm{v}$ podobě strukturovaných rozhovorů $\mathrm{s}$ odborníky (viz tabulka 1) bylo formulováno 26 parametrů kvalitní výuky o technice, které byly určeny

k pozorování a posuzování. Kritéria pro jejich ustanovení vycházela z těchto předpokladů:

- parametr je v principu možné pozorovat ve vyučovacích hodinách;

- parametr byl uváděn experty jako častý;

- pro parametr se mohla vytvořit škála;

parametry dohromady tvoří komplexní a logickou množinu.

\footnotetext{
5 Strategie vzděláváni 2020 (http://www.vzdelavani2020.cz/) uvádi nutnost reflektovat změny ve společnosti (styl života, rodina, způsob uvažováni dospělých $i$ dětí, ekonomická krize a jeji dopad), které maji významný dopad na to, jak rodiče, dèti a mladi lidé přistupuji ke vzdélávání a školství. Strategie formuluje vize toho, jak má vzdělávaci systém vypadat v horizontu nejméně jedné generace a jaký význam má mit pro kvalitu života, demokracii a konkurenceschopnost České republiky.
} 


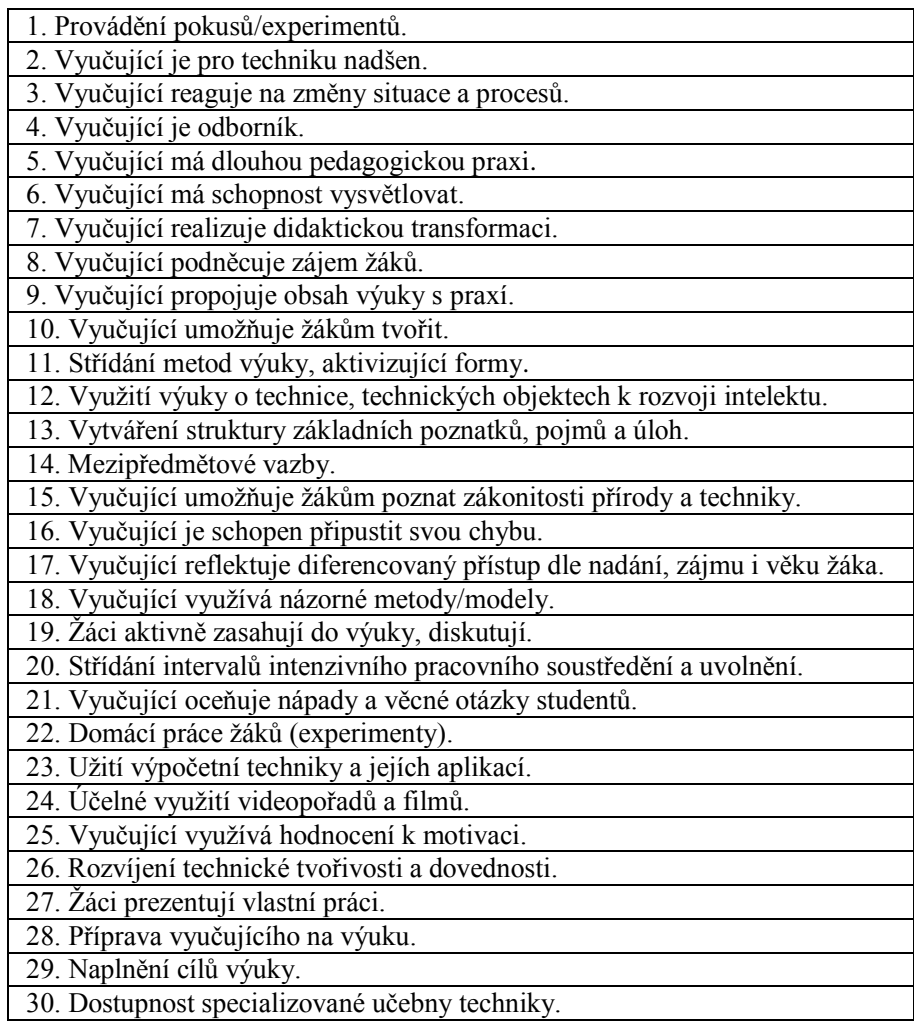

Tabulka 1 Parametry kvalitni výuky o technice dle odborniku z praxe

Vybrané parametry byly pro přehlednost rozděleny do 4 skupin - viz tabulka 2 .

Jednotlivé parametry byly doplněny posuzovací škálou (využili jsme vlastnosti bipolárních škál i vlastnosti tzv. Likertových škál, které se skládají z výroků), která tvoří výzkumný nástroj umožňující zjišt'ovat míru vlastnosti zkoumaného jevu. Podle [9] jsou tyto škály obvykle $v$ lichém pořadí čímž je ovšem vytvořena souměrná míra. V našem případě byla zvolena ale čtyřstupňová škála, která lépe odpovídá našim potřebám posuzování při vyšším počtu stupňů by mohlo vést intuitivním odhadům a zkreslení výsledků. Bohužel ze zkušeností vyplývá, že ne vždy definování jednotlivých stupňů je zcela jednoznačné [9] a posuzovatelé se tedy musí přiklonit $\mathrm{k}$ tomu stupni, který nejlépe dle jejich názoru vystihuje zkoumané jevy.

\begin{tabular}{|l|}
\hline $1 . \quad$ Podmínky \\
\hline 1.1 Odbornost učitele - znalosti, dovednosti, srozumitelnost \\
\hline 1.2 Osobnost učitele - trpělivost, vstřícnost \\
\hline 1.3 Tvořivost učitele - pružnost, iniciativa, nápady \\
\hline 1.4 Použití pomůcek - modely, zapojení žáků \\
\hline
\end{tabular}




\begin{tabular}{|c|}
\hline 2. Organizace, formy a metody \\
\hline 2.1 Výklad - účelnost, přiměřenost \\
\hline 2.2 Heuristická metoda - vhodnost, přiměřenost \\
\hline 2.3 Experimenty - rozbor, vysvětlení, názornost \\
\hline 2.4 Stř́ídání metod, jejich vhodnost \\
\hline 2.5 Rozvoj představivosti \\
\hline 2.6 Logické procesy (analýza, syntéza, dedukce, indukce) \\
\hline 2.7 Kritické myšlení - rozvíjení \\
\hline 2.8 Struktura poznatků - pojmy, souvislosti \\
\hline 2.9 Práce $\mathrm{s}$ textem \\
\hline 3. $\quad$ Motivace a hodnocení \\
\hline 3.1 Podchycení zájmu studentů \\
\hline 3.2 Zájem o techniku, technické obory \\
\hline 3.3 Propojení s praxí a životem \\
\hline 3.4 Vlastní zkušenosti \\
\hline 3.5 Mezipředmětové vztahy \\
\hline 3.6 Aktivizace žáků \\
\hline 3.7 Nároky na žáky - přiměřenost, diferencovanost \\
\hline 3.8 Hodnocení jako motivace \\
\hline 4. Komunikace a výchova \\
\hline 4.1 Komunikace žáků, zejména technická \\
\hline 4.2 Vztah žáků k sobě, k ostatním lidem, ke světu, technosféře \\
\hline 4.3 Kázeň \\
\hline 4.4 Pracovní klima \\
\hline 4.5 Aktivní učení \\
\hline
\end{tabular}

Tabulka 2 Parametry kvalitní výuky o technice ve výzkumu

Na níže uvedených průbězích (obr. 3 - 6) jsou prezentovány dílčí výsledky šetření pro jednotlivé parametry $\mathrm{v}$ podobě aritmetických průměrů (osa y) stupňů/škály príslušného parametru.

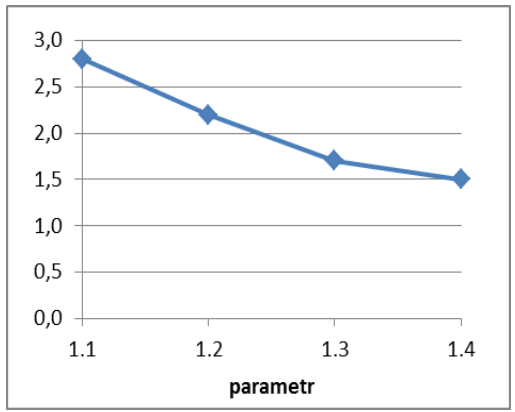

Obr. 3 Parametr 1 - Podminky 


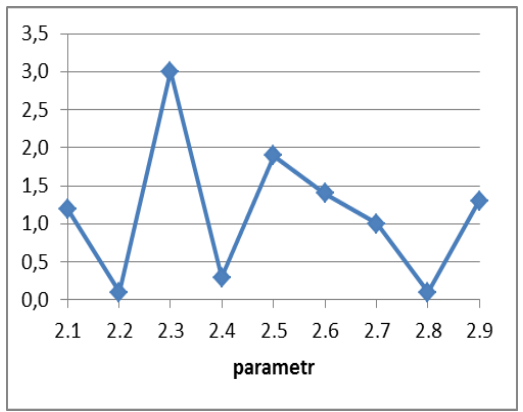

Obr. 4 Parametr 2 - Organizace, formy a metody

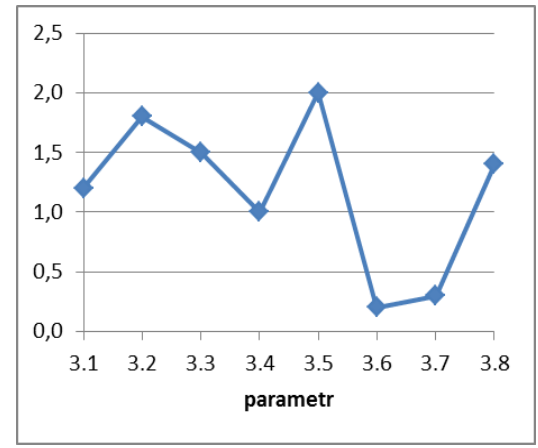

Obr. 5 Parametr 3 - Motivace a hodnocení

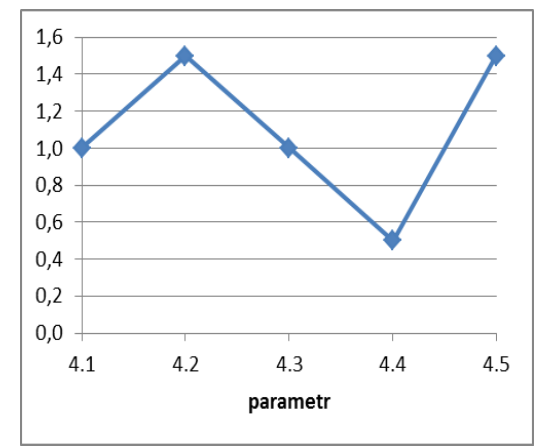

Obr. 6 Parametr 4 - Komunikace a výchova

Výsledky získané výzkumem by mohly přispět $\mathrm{k}$ pochopení příčin kvalitní výuky a následně $\mathrm{k}$ pochopení prŕčin kvalitních výkonů žáků. Učitel je po osobních předpokladech žáka a vlivu jeho rodiny, nejvýznamnějším činitelem, rozhodujícím o úspěchu žáka ve vzdělávacím procesu. Nástroj sledování kvality výuky je tudíž 
potřebný pro získání konkrétních informací, které mohou napomoci sledovat, hodnotit a zlepšovat kvalitu vyučování ze strany učitele s ohledem na vzdělávací výsledky žáků.

Výzkumy ve světě i u nás dlouhodobě prokazují, že nejúčinnější cestou ke zlepšení kvality výuky je podpora učitelů př́mo při jejich činnosti tj. ve výuce [10], [11], [12].

\section{Závěr}

Pojem kvalita výuky je pojmem, který je nutné sledovat v mnoha vzájemně propojených a ovlivnitelných rovinách zahrnujících vstupy a výstupy, procesy výuky, přidanou hodnotu činitele výuky apod.

Obecně při utváření kvality výuky sehrávají rozhodující úlohu žáci, rodina, škola, učitelský sbor a kurikulární dokumenty. V̌̌echny tyto oblasti/roviny mají stěžejní vliv na určení kvality výuky, přičemž se samozřejmě nejedná o proces jednorázový, ale neustále se opakující a proměnlivý v čase.

Základním problémem pro získání relevantních údajů o kvalitě dané výuky je již samotné vymezení toho, co je stěžejní pro analyzování, pozorování a posuzování a co lze tedy považovat za základní a stěžejní parametry kvalitní výuky, přičemž se prioritně musí jednat o parametry umožňující časovou opakovatelnost. Je pochopitelné, že v různých školách, třídách jsou různí žáci, kteří tak rozdílně reagují na výuku i na samotného učitele, je rovněž pochopitelné, že jsou různí učitelé a tedy, že dochází $\mathrm{k}$ různé interakci, do které navíc vstupuje více aktérů v rámci školy i mimo ni.

Při vlastním expertním šetření jsme tak ani neočekávali vyčerpávající a jednoznačná poučení o tom jak kvalitně učit. Výsledkem jsou pouze náměty na parametry kvalitní výuky obecně využitelné pro určení kvalitní výuky $\mathrm{v}$ technicky orientovaných předmětech na základní škole.

\section{Literatura}

Průcha, J. Walterová, E. \& Mareš, J. (2013).. Pedagogický slovník. 7. aktualizované a rozšiřrené vyd. Praha: Portál.

Posch, P. (1999). Qualitätsevaluation und Qualitätsentwicklung im Schulwesen. In Erziehung und Unterricht, č. 5-6. Wien: OBV ET HPT VerlagsGmbH.

Rýdl, K. (2002). K pojetí kvality ve školství a jejímu hodnocení. E-Pedagogium. 2002, roč. 2, č. 1, s. 104-123.

Slavík, J., Janík, T., Jarníková, J. a Tupý, J. (2013). Zkoumání a rozvijení kvality výuky $v$ oborových didaktikách: metodika $3 A$ mezi teorii a praxí. 7. aktualizované a rozšsiřené vyd. Praha: Portál.

Janík, T. (2013). Kvalita (ve) vzdělávání: obsahově zaměřený přistup ke zkoumáni a zlepšování výuky. 1. vyd. Brno: Masarykova univerzita, 2013, 434 s. Syntézy výzkumu vzdělávání, sv. 1.

Reynolds, D. \& Cuttance, P. (1992). School Effectiveness. A\&C Black.

Defining Quality in Education. (2000). A paper presented by UNICEF at the meeting of The International Working Group on Education Florence, Italy June 2000. Dostupné na: $<\mathrm{http}: / /$ www.unicef.org/education/files/QualityEducation.PDF>

Ditton, H. (2002). Unterrichtsqualität - Konzeptionen, methodische Überlegungen und Perspektiven. In. Unterrichtswissenschaft 3/2002, s. 197-212. Weinheim: Juventa. Gavora, P. (2000). Úvod do pedagogického výzkumu. Překlad Vladimír Jůva. Brno: Paido. 
Zajda J., Bachus, K. and Kach, N. (1995). Excellence and Quality in Education. James Nicholas Publishers.

Quality in education and training. (1993). Association for Educational and Training Technology. University of Virginia. Kogan Page.

Watson, K., Modglil, C. \& Modgil, S. (1997). Quality in Education. Cassell. 